\title{
Death of children by domestic accidents: unveiling the maternal experience
}

\author{
Morte de crianças por acidentes domésticos: desvelando a experiência materna \\ Muerte de niños por accidentes domésticos: desvelando la experiencia materna
}

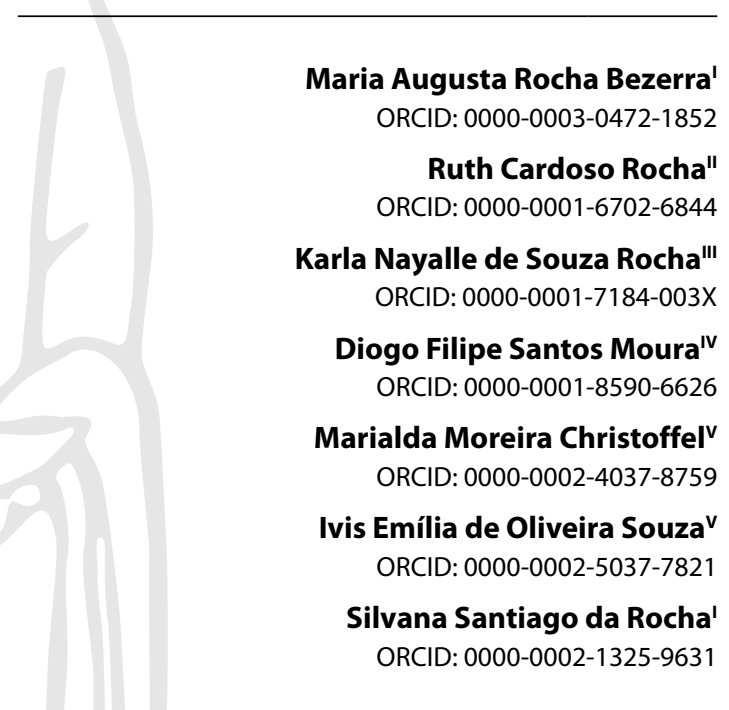

'Universidade Federal do Piauí. Teresina, Piauí, Brazil. "Universidade Federal do Piauí. Floriano, Piauí, Brazil. IIIInstituto Federal da Paraíba. Patos, Paraíba, Brazil.

"Instituto Federal do Piauí. Floriano, Piauí, Brazil. vUniversidade Federal do Rio de Janeiro. Rio de Janeiro, Rio de Janeiro, Brazil.

How to cite this article:

Bezerra MAR, Rocha RC, Rocha KNS, Moura DFS, Christoffel MM, Souza IEO, et al. Death of children by domestic accidents: unveiling the maternal experience. Rev Bras Enferm. 2022;75(4):e20210435 https://doi.org/10.1590/0034-7167-2021-0435

Corresponding author: Maria Augusta Rocha Bezerra E-mail:mariaaugusta@ufpi.edu.br

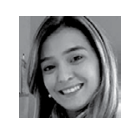

EDITOR IN CHIEF: Antonio José de Almeida Filho ASSOCIATE EDITOR: Ana Cristina Silva

\section{ABSTRACT}

Objectives: to unveil the meanings of mothers whose children died as a result of domestic accidents in childhood. Methods: a qualitative research, in the light of Heideggerian phenomenology, with ten mothers whose children died from domestic accidents. It was carried out in a municipality of the Northeast Region of Brazil through phenomenological interviews between May and June 2017. The existential analytic was constituted by the comprehensive moments of the Heideggerian method. Results: the meanings unveiled pointed out that, to understand the sudden death of her child, the mother oscillates between feeling guilty, pointing and denying guilt. She reports emptiness, permanent pain, non-acceptance of her child's death, and the desire to keep him in her life. In this journey, the fear that brings limitations to her life and that of her other children is revealed. Final Considerations: it was revealed that the death of the child in infancy compromises the integrality of being a mother, indicating the need for systematic and continuous care for the adequate management of the emotional and social effects.

Descriptors: Death; Child; Domestic Accidents; Maternal Behavior; Bereavement.

\section{RESUMO}

Objetivos: desvelar os sentidos de mães cujos filhos morreram em decorrência de acidentes domésticos na infância. Métodos: pesquisa qualitativa, à luz da fenomenologia heideggeriana, com dez mães cujos filhos morreram por acidentes domésticos. Realizou-se em município da Região Nordeste do Brasil mediante entrevista fenomenológica entre maio e junho de 2017. A analítica existencial constituiu-se pelos momentos compreensivos do método heideggeriano. Resultados: os sentidos desvelados apontaram que, para compreender a morte repentina do filho, a mãe oscila entre sentir-se culpada, apontar e negar culpados. Refere vazio, dor permanente, não aceitação da morte do filho e desejo de mantê-lo em seu vivido. Nesse caminhar, revela-se o medo que traz limitações para sua vida e a de seus outros filhos. Considerações Finais: desvelou-se que a morte do filho na infância compromete a integralidade do ser mãe, indicando a necessidade de cuidado sistematizado e contínuo para a condução adequada dos efeitos emocionais e sociais.

Descritores: Morte; Criança; Acidentes Domésticos; Comportamento Materno; Luto.

\section{RESUMEN}

Objetivos: desvelar sentidos de madres cuyos hijos murieron en consecuencia de accidentes domésticos en la infancia. Métodos: investigación cualitativa, basada en la fenomenología de Heidegger, con diez madres cuyos hijos murieron por accidentes domésticos. Realizado em municipio del Nordeste brasileño mediante entrevista fenomenológica entre mayo y junio de 2017. Analítica existencial constituida por momentos comprensivos del método de Heidegger. Resultados: los sentidos desvelados apuntaron que, para comprender la muerte repentina del hijo, la madre oscila entre sentirse culpable, apuntar y negar culpables. Refiere vacío, dolor permanente, no aceptación de la muerte del hijo y deseo de mantenerlo en su vivido. En ese caminar, revela el miedo que trae limitaciones para su vida y sus otros hijos. Consideraciones Finales: se desveló que la muerte del hijo en la infancia compromete la integralidad del ser madre, indicando la necesidad de cuidado sistematizado y continuo para conducción adecuada de efectos emocionales y sociales.

Descriptores: Muerte; Niño; Accidentes Domésticos; Conducta Materna; Luto. 


\section{INTRODUCTION}

Accidents are among the leading causes of death in children, and a significant portion of these occur at home ${ }^{(1)}$. In the United States of America (USA), they are the leading cause of death among children and adolescents ages one to 19, and in 2014, they accounted for $34.4 \%$ of all deaths ${ }^{(2)}$. In Brazil, data from the Mortality Information System (MIS) of the Ministry of Health (MH) showed that in 2015, there were 3,311 deaths of children under 10 years of age throughout the country due to external causes, including accidents and violence. Of these, 581 (17.5\%) were caused by drowning and accidental submersion, $127(3.8 \%)$ were due to falls, and $89(2.6 \%)$ resulted from burns, accidents that are common to occur in the home ${ }^{(3)}$.

The high rate of domestic accidents among Brazilian children impelled the $\mathrm{MH}$ to develop legal and material devices to guide health professionals in the orientation of caregivers and family members on preventive strategies ${ }^{(4)}$. These actions fit mainly with the role of Primary Care (PC) professionals because of their proximity to children and families in the communities they work with and the opportunity to conduct educational activities through home visits $^{(5)}$. However, in many cases, there is negligence in this type of approach, which can hinder the assistance to this population to reduce morbidity and mortality resulting from this disease ${ }^{(6)}$.

Childhood death from domestic accidents triggers major implications in the daily lives of those involved. Mothers are often at higher risk of complicated bereavement than fathers ${ }^{(7)}$. From the moment the physical relationship with the child ends, a long process of maternal grief begins. Generally, this grief process is complex and multifaceted and involves adaptive responses to grief $^{(8)}$. In particular, mothers whose children died younger are more affected than those who lost older children ${ }^{(7,9)}$.

Regardless of the cause, the death of a child is always a difficult experience for most mothers ${ }^{(8,10-12)}$. However, for mothers whose children died suddenly and unexpectedly, there is no opportunity to prepare for the loss or grief support, triggering, in general, a more intense grief reaction in these mothers than in those whose children died of a chronic condition. Because of the suddenness, they are at greater risk of developing mental health problems $s^{(7,10)}$, such as complicated grief, depression, and clinically significant post-traumatic stress disorder ${ }^{(13)}$, in addition to anxiety and use of psychotropic medications ${ }^{(14)}$.

It is necessary to consider that the impacts of infant death also involve social aspects related to persistent maternal isolation, as well as implications that may extend to other children living in their families ${ }^{(15)}$. In this context, the nurse must be attentive to the bereaved mother, in order to make nursing diagnosis, pointing out the degree of maternal dependence and, through technical, social and affective skills, establish the best intervention in each case ${ }^{(16)}$.

Some investigations involving mothers whose children died in infancy have focused mainly on the identification, quantification and characterization of grief reactions, with the objective of identifying mothers at risk of developing complicated or pathological grief $f^{(9,17)}$. However, the complexity of the theme requires a focus on inter-subjective relationships and on the understanding of what mothers experience ${ }^{(12)}$. Despite the growing scientific production in this field, the meaning of the experiences of mothers whose children died in infancy needs constant and continuous understanding ${ }^{(18)}$.

Global child mortality due to accidents is among the few causes with no projected decrease in cases by the year $2030^{(19)}$. Given the urgent need to develop preventive measures to reduce the number of deaths among children from this cause, it is also essential to offer attention and care in order to provide adequate support to families, especially to mothers after the death of a child, in order to promote physical, mental and social well-being among these women ${ }^{(20)}$.

With the intention of understanding the phenomenon, the following research guiding question was established: How do mothers whose children died as a result of domestic accidents in childhood, mean their experiences?

\section{OBJECTIVES}

To unveil the meanings of mothers whose children died as a result of domestic accidents in childhood.

\section{METHODS}

\section{Ethical aspects}

The study was approved by the Research Ethics Committee of the Federal University of Piauí, seeking to meet the ethical and legal requirements of the National Health Council with regard to research involving human beings. Before the interviews, the participants read and signed the Free and Informed Consent Term. To ensure anonymity, the people involved had their identification coded.

\section{Theoretical and methodological framework}

The Heideggerian phenomenological method allows the phenomenon to be unveiled, manifesting the meaning of being and the fundamental structures of Dasein. It has the character of refusing cover-ups and distortions, since the phenomenon, most of the time, is misunderstood or insufficiently interpreted from the ontological point of view. In this way, Heidegger proposes phenomenology as the access way and the mode of proof to determine what should be the subject of ontology, in order to ensure its legitimacy. It establishes that ontology is only possible as phenomenology and proposes the phenomenological concept of phenomenon as that which is shown, the being of beings, its meaning, its modifications and derivations. Under these conditions, the showing of oneself is not just any showing of oneself and, much less, a manifestation ${ }^{(21)}$.

\section{Methodological Procedures}

The data collection period occurred between May and June 2017. For the field phase, the community health agents (CHAs) of PC collaborated to indicate possible participants who fit the pre-established criteria for the study. A deadline was agreed upon to allow these professionals to list the cases of domestic accidents in childhood in their micro-areas. A schedule of activities 
was built so that, individually, all the CHAs could indicate the homes of possible participants. These professionals informed the mothers about the study and scheduled a date and time for a home visit by the researcher. On the scheduled day, the $\mathrm{CHA}$ waited for the researcher at the Basic Health Units (BHU) to accompany her on the visit.

At this point, before leaving for the meeting with the possible participant, the CHA only informed the mother's name and the age of the child. The researcher chose not to know details of the domestic accident and the participant's life prior to the meeting, in order to reduce assumptions and preconceptions, impregnated with the dominant understanding of traditional theories and opinions on the being of the child ${ }^{(22)}$. During the home visit, the researcher followed up the introduction and presented the study proposal to the potential participants and, upon acceptance, scheduled the interview, whose location; date and time were left to their discretion.

\section{Type of study}

Qualitative research, based on the theoretical-philosophicalmethodological framework of Heideggerian phenomenology ${ }^{(21)}$. The research met the items on the consolidated criteria for reporting qualitative research (COREQ) checklist.

\section{Study Scenario}

Study developed in the PC of a municipality in the Northeast Region of Brazil. According to the National Register of Health Establishments of Brazil, this PC is composed of 24 health establishments classified as Health Program/Project or BHU. Data provided by the Municipal Health Secretariat (MHS) indicate that the municipality has $14 \mathrm{BHUs}$ located in urban areas and ten in rural areas.

\section{Data source}

The CHAs indicated 17 names of mothers whose children died as a result of domestic accidents in childhood, but only ten participants were included. It is noteworthy that, by performing the data production concomitantly with the analytical movement, it was possible to conclude the field stage when the meanings expressed in the mothers' reports showed sufficient essential structures to understand the investigated phenomenon ${ }^{(22)}$. This made it unnecessary to use the sampling process. All the mothers who were invited agreed to contribute to the research.

Inclusion criteria were established as follows: mothers aged 18 years or older; and that the domestic accident had occurred with the child in the age range between one day of birth and 12 years. The exclusion criteria were mothers who presented alterations in the cognitive thought process. It is emphasized that there was no delimitation of time elapsed between the child's death and that moment in which the mother found herself, because the experience of mothers is permanently affected after the death of a child ${ }^{(18,23)}$.

\section{Collecting and organizing data}

As a technique, we used the phenomenological interview, which involves a process of interaction and dialogue between the researcher and the participant from the moment of the existential and inter-subjective encounter. In this encounter, the researcher sought to consider the subjectivities of each participant and to place herself in a position of active and attentive listening, reducing assumptions and value judgments ${ }^{(24)}$.

The guiding question that drove the interview was, "What did the death of your child/children by a domestic accident mean?" Other empathic questions were used throughout the interview when it was necessary to clarify aspects emerging from the participants' discourse. However, care was taken not to induce answers or express prejudices, seeking to resume, based on the participant's own words/expressions/phrases/ideas, issues of research interest that needed to be elucidated, in order to better understand the meanings ${ }^{(25)}$.

The interviews were conducted individually, lasting between 30 and 90 minutes, in a place previously agreed with the participant, usually at home or in a private room provided by the BHU. The meetings were audio-recorded on a digital recorder, with prior authorization and information validated as to content by the participants who, at the end of the interview, were asked if they would like to make any additions to the statements. The recording was transcribed in full with the support of Microsoft Word.

For identification purposes, the participants were designated with a code beginning with the letter $M$ followed by the Arabic number corresponding to the order in which the interviews were conducted (M1, M2, M3... M10). The name of the child who died because of a domestic accident was replaced by the code consisting of the letter $\mathrm{F}$ followed by the Arabic number corresponding to the order in which the mother was interviewed (F1, F2, F3... F10). Moreover, the names of other people involved in the participants' lives, mentioned in their speeches, were randomly substituted.

\section{Data analysis}

The analysis movement concomitant to the field stage began with listening to and transcribing the recordings, followed by reading the transcripts in order to differentiate essential structures from occasional ones, having the objective of the investigation as a guide for the former, which are revealing of the phenomenal dimension ${ }^{(25)}$.

The analysis based on the Heideggerian methodological reference involved two methodical moments based on Heidegger's phenomenology and grounded in the work "Being and Time": the vague and median understanding; and the interpretative or hermeneutic understanding. The first, vague and median understanding, is the description of the experience of mothers based on the experience of losing a child to a domestic accident. This experience lived by the mother may be impregnated with common sense, constituting a source of dominant understanding ${ }^{(21)}$. The second part of the methodical moment is hermeneutics, which consists of an analysis for interpreting this experience, removing the dominant understanding, in order to obtain the true experience, which would be characterized by the phenomenon of the experience itself ${ }^{(21,26)}$.

Based on this analysis, Meaning Units were constructed, titled based on the meaning of the experience attributed by the participants. Thus, three thematic units emerged, namely: 1) 
"Denying their guilt for the death of their children, because they took care of them... and pointing and denying the existence of guilty parties"; 2 ) "Remembering how they felt when they heard about the death of their son... and how they still don't understand what happened"; 3) "Feeling fear that brings uneasiness and limitations to their life and that of their other children".

\section{RESULTS}

Ten mothers aged between 28 and 82 years, mostly married or in a stable union $(n=6)$, participated in the research. Regarding education, two considered themselves to be illiterate, three reported having completed elementary school, two attended incomplete elementary school, two attended incomplete high school, and one said she was attending college. Most of them $(n=4)$ said their occupation was performing activities at home. Regarding the domestic accidents that victimized the children, three involved poisoning; three, accidents by electrical shock; three, drowning; and one involved choking. Regarding the sex of the victims, there were six boys and four girls, with ages ranging from one to 11 years old. The time elapsed since the accident varied between one and 53 years.

Considering the referential used, the data analysis made it possible to understand that, for the mothers participating in the study, the experience of the death of their child due to a domestic accident during childhood means:

\section{Deny their guilt for the death of their children, because they took care of them... and point out and deny the ex- istence of guilty parties}

Mothers whose children died because of a childhood domestic accident denied feeling guilty for their children's death, although this guilt was sometimes attributed to them by themselves and sometimes by society, represented by neighbors and health professionals.

[...] they were not mistreated, they were well taken care of [...] we were always focused on them, worried [...] because the accident was due to disobedience on their part, they already understood things [...] I told his [older] sister [F1] not to leave the house with them, and she insisted on taking them to the river [...] but it was a fatality, it was not my fault, nor his [husband's] fault [...] God gave me and God took away. God did not allow him to stay with me. (M1)

[...] / worked, but I arrived at noon to fix her, comb her hair, make food, give her lunch, send her to school, I worried a lot about taking care of her [...] sometimes I feel that I am to blame. But, I wasn't at home, I was working to support her and her brother [...] / don't think it was anyone's fault. (M2)

[...] my husband's niece kept picking on me while my daughter was eating [...] when I saw it, I said: Antonia, you killed my daughter. I noticed that $F 3$ was already choking, she wasn't talking anymore [...] then Pedro [husband] picked her up and took her to the hospital. At that time, there was no medical board, there was nothing, just a few "little doctors" who didn't know anything [...] the doctor pushed the bone that F3 was choking on and my husband accepted it. If I had gone, I would not have accepted [...]. (M3)
[...] I was busy, he came and got the bowl and ate, without me knowing [...] I didn't see when he ate. There are days that I think I should have paid attention when he got the yuca, but I didn't see, I wasn't to blame [...]. (M5)

People wanted me to sue the owner of the house [where the accident occurred] to make her pay, because her refrigerator was old [...] it wasn't carelessness, many people accused me, that it was carelessness [emotional], my neighbors, mainly [...] But, because it was not to be mine. Because it was her day [to die]. (M6)

[...] the doctor told me that if I had put my finger in her throat to make her vomit [...] [she wouldn't have died] but I couldn't guess that she was eating manioc [...] I was desperate [...] it meant a lot of sadness and pain that every mother feels. I can't explain it, you can't measure it [...]. (M9)

One thinks that God doesn't even exist. Because everything happens to others, when they knock on our door, we wonder, "Why did He do it?" (M10)

They justified the absence of guilt based on the affirmation and reaffirmation of the care they provided to the child before the accident occurred. This care was expressed by the participants considering the denial of negligence or neglect, the guidance provided to the children, the protection provided, the absence of violence, the "good care" provided, the focus given to the child (feeding, clothing), the concern for the child, the supervision and domestic and external work to provide for the children's needs.

They understood that the child himself could have been able to avoid death, by referring that he was old enough to understand risk situations. On the other hand, they considered that the child could have been taken care of by other people and thus tried to point out the culprits for the child's death. They also attributed to God the responsibility for what happened, showing themselves resigned to this fate. At the same time, they mentioned that there was no blame, attributing the domestic accident to fatality and fate, reproducing popular sayings.

\section{Recall how they felt when they heard about the death of their child... and how they still don't understand what happened}

In their speeches, the participants meant that when the child's death was ascertained, they were confronted with a sense of emptiness, which was revealed in different ways.

[...] it is as if we were here and out of nowhere everything disappeared [...] you have no ground, you are airborne [...] I never used any kind of drug, but I think it is the same feeling [...] I remember the moment, the news, then one speaks, another speaks and you are there, it seems that you are just hearing a buzzing sound [imitates the sound of the buzzing sound] [...] You can't do anything [...] sometimes, I remember what happened, and it gives me that despair again, the despair of not being able to do anything. It's a time when you see that you are totally impotent. [...] There is no reasonable explanation [...] The pain of loss is a different pain than when you lose a loved one, a child, it is different when a parent or grandparent dies, I don't think it can be compared [...] so, it was all too difficult. (M1) 
[...] / felt a huge emptiness [...] my neighbor said he saw her with an iron in her hand, but at that time, I saw nothing in her hand [...]. (M2)

[...] It was too much sadness. Too much, I suffered a lot, I cried a lot, night and day. (M3)

[Crestfallen] [...] I lost sight of the world. I spent hours without seeing the world [snaps fingers] [cries copiously] [...] if it was something he was already sick, but it was suddenly [...]. (M5)

When they broke the news, my pressure dropped for good. I couldn't see anything [...] I was desperate [...] / couldn't do anything. I lost my daughter, that's it! We never expected it, it was something so sudden [...] I suffered a lot for her death [...] a great pain. (M6)

[the loss of her child] meant a lot of sadness and pain that every mother feels! I can't explain it, I can't measure it [...]. (M9).

Mothers also compared the impactful sensation of the news/ vision of their child's death to the numbness caused by drug use, which triggered disorientation and disorganization. They reported physical sensations that involved, above all, the sense of hearing and sight, generating tinnitus and decreased visual acuity/blindness, respectively. They recounted despair at the helplessness and incapacity in face of the irreparable loss; and, as they recalled the experience, they relived these feelings.

The mothers expressed that the death of their children generated deep suffering in their experiences, reported as inexplicable, incomparable, immeasurable, unexpected, difficult and sad pain. They expressed a lot of difficulty in giving meaning to this pain, emphasizing that they couldn't find references to compare it to. They highlighted that the difference of this suffering in relation to other losses, such as the death of other relatives, is in the intensity and in the characteristic of being an unexpected fact, for having happened in childhood and having been an accident.

\section{Feeling fear that brings uneasiness and limitations to your life and the lives of your other children}

When facing daily life after the death of their child, the mothers understood themselves with fear, which brought limitations to their lives and to the lives of their other children. This fear refers to the possibility of new domestic accidents, among other factors that could bring risks to their lives.

After the event, I said I did not want to have children [...] I was afraid of getting pregnant. Today, I don't have the courage to leave him [the child born after the death of his brother by accident] alone, I don't trust anyone [...] I stopped working because I am afraid to leave him with someone, because being with me, I am watching [...] He goes to school, but the heart is tight. I am only at peace when I pick him up from school and I am with him at home, because I am afraid of the phone ringing and saying "your child was sick, something happened" [...] / am afraid of losing him again [...]. (M1)

My other boy, the youngest, I don't let him, he doesn't use an iron [...]. (M2)

[...] it's been a long time since I had this cassava business at home, I didn't want it anymore. (M5)
Death of children by domestic accidents: unveiling the maternal experience Bezerra MAR, Rocha RC, Rocha KNS, Moura DFS, Christoffel MM, Souza IEO, et al.

[...] / don't go to this riverbank anymore [...] neither I go and neither they [children] go, I don't let them, because I am afraid [...]. (M8)

I saw that it happened in other people's families, but in our [family], we never think that it's going to happen [...] since then, I'm like this, with fear. My 2-year-old girl already knows, she doesn't turn off the fan, she doesn't turn on the light, she doesn't put her hand in the socket. Because here she doesn't let us. If we go out, I leave everything plugged in. (M10)

They listed the reasons for fear, which were directly and indirectly related to the domestic accident that victimized their children: fear that they or another child will suffer the same domestic accident; fear of leaving their children under the supervision of other people; fear that their children will suffer other accidents when they are not under their supervision; fear of receiving, again, the news that something happened to their children.

Regardless of the time elapsed after the death of their children, mothers imposed changes and limitations in their family routines. They reported that, due to the trauma caused by the death, they delayed having new pregnancies; they did not work outside the home; they avoided leaving their children with other people, because they trusted only their supervision; they did not leave their children alone; they did not allow their children to handle objects or similar or to experience routines similar to those that caused the domestic accident that triggered the death of their child.

\section{DISCUSSION}

Before entering this stage, it is necessary to explain some Heideggerian concepts that supported the objective of the study. The study of the human being living in society in a certain context and under certain conditions was developed. This thought is expressed by hyphenated words, with the purpose of etymological preservation to indicate the root and the agglutinations; and by the use of italics, to highlight words/expressions from Martin Heidegger's theoretical referential. It is also clarified that this philosopher uses the term ente (being) to refer to people and everyday things, and Dasein (being-there) to refer to people in essence, and the term -there indicates that one assumes the place of protagonist of his or her experiences, experiences, and relationships ${ }^{(21,27)}$.

In this study, the Heideggerian hermeneutic enabled the unveiling of mothers as being-there-mother. The composition of the hyphenated word being-in-the-world refers to the being that shares experiences in constant relationship with oneself, other people, and things ${ }^{(28)}$.

Following this direction as being-in-the-world, the mother is, essentially, occupation, in the sense of the exercise of maternity. Therefore, by denying the guilt for her child's death, she refuses to accept the responsibility for what happened based on the rationalization grounded in her dealing with her child in her daily life, i.e., through the care she gave him $^{(21)}$. In this context, the being-there-mother plays the role that has always been determined as her responsibility and is therefore familiar to her.

The speeches reveal that the mother-being is immersed in the busyness of daily life and lost in the publicity of the impersonal, a 
Heideggerian category that establishes the whole way in which the world and the being-there-mother are interpreted ${ }^{(21)}$. The mother constantly compares herself with the others, trying to keep up with them, equal them or surpass them. By comparing herself with other mothers, with the perspective of diminishing her differences in relation to the others, the mother shows herself within the Heideggerian category of estrangement, which means to transpire the other mothers' way of existing. In this sense, by denying any guilt for her child's death, she refuses to be the mother of a child who died because he was not properly cared for. Because of this, she hastens to show and resume repeatedly in her speeches the tasks and care that she performed and that, in her understanding, were capable of adjectivating her as a good mother. In this way, she strays from the existential path and, by annulling herself, she stops becoming "herself" and becomes what others want her to be: impersonal and inauthentic in her experience ${ }^{(21)}$.

The mother, when talking about her experience, tries to understand the sudden death of her child and, to do so, oscillates between pointing and denying the existence of culprits. Sometimes she blames the child herself or attributes the accident/death to chance or fate. This blaming of the other is a result of feelings of incapacity to keep the child alive and puts the bereaved women in a situation of suffering, mainly because they lose the possibility of reparation ${ }^{(29-30)}$. By putting the blame on others, the mother seems to un-blame herself. While she says she knows that the domestic accident that victimized her child is not her fault, she feels guilty at times. This ambiguity permeates the mother's discourse at several moments.

In search of relief and comfort for her revolt, the mother shows herself in a category of existence that Heidegger called talkativeness, which is the speech disarticulated from her particular experience. This speech, in turn, conveys a general interpretation, which is absorbed through the experience related to the customs of the culture in which she is inserted. The mother's view that the child's death by a domestic accident was a fatality or because it was her destiny is not based on her personal experience, but on the fact that everyone quotes this popular saying ${ }^{(21)}$.

Through the influence of a religious thought of the already emphasized cultural influence in which the mother is inserted and instigated by the talkativeness, she holds God responsible for the death of her child, by stating that "God gave it to me and God took it away", among other sayings built on the foundation of a discourse ready and spread in the religious sphere to promote the comfort of those who suffer for the loss of deceased loved ones. Through such accountability, they find relief, and religion presents itself in the world of these mothers not only as a doctrine, but also as something that gives meaning to their existence and provides comfort and support in situations related to finitude ${ }^{(31)}$.

With the death of the child, a bond is broken, but in the break, the bereaved mother remains connected to him, often more strongly than before. It is precisely this contradiction that can seem unbearable to her. The mother may rebel against the fact of death, accuse herself, family members, or doctors of malpractice, and the same time show anger against fate or $\operatorname{God}^{(30)}$.

Regardless of rationalizing the facts involving the accident and the death of their child, mothers often examine various ways in which they could have anticipated the occurrence and intervened, even if such expectations are unrealistic. Mothers need to forgive themselves, which can take a long time to happen. Certainly, reality reinforcement from other trusted people accelerates this healing ${ }^{(32)}$. For this reason, maternal bereavement care, still fragile in the Brazilian context in hospitals and/or in $\mathrm{PC}^{(33)}$, is essential. Nurses and other health care professionals should pay careful attention to the meanings mothers attach to the loss, should support spiritual values, and strengthen effective coping mechanisms for bereaved mothers ${ }^{(34)}$.

For this, the nurse needs to be prepared to perform active listening considering the aspects related to maternal guilt, make nursing diagnoses directed to the needs of the bereaved mother and, based on these, prescribe individual and collective interventions, which include welcoming, constitution/forwarding to therapeutic groups and follow-up by the reference team and matrix support.

When remembering the definitive absence of the child, as expressed in the second category, it is perceptible in the mother's reports (also under the influence of the talkativeness) the feeling of emptiness, described as numbness and marked by the loss of adequate perception of reality ${ }^{(21)}$. It is inferred that the mother ceases to experience the moments of care that were her responsibility, that filled her life, her existence as a mother. Her whole life becomes affected and unstructured because, with the death of her child, daily life loses its meaning: the usual familiarity collapses $^{(21)}$. This is because death leads to separation not only from inter-corporeality, but also from the shared world, which includes common habits and practices, especially childcare. The bereaved mother is suddenly torn out of this shared world. Now the family environment becomes a place of painful absence and emptiness ${ }^{(30)}$.

In this process, the non-acceptance of the sudden death of the child and the permanent pain for the fatality are visible, demonstrated by the mothers' significant effort to explain their suffering. Although there is perceived difficulty in reporting, explaining, or even understanding this pain, talking about the child's death can benefit these women to the extent that they are able to share a real experience ${ }^{(35)}$ and bring the deceased child into your world, easing the pain of loss by maintaining continuous contact with him/her ${ }^{(30)}$.

It is noteworthy that the intense grief reported by mothers is independent of the time elapsed since the child's death. For this reason, traditional approaches from Western culture with a focus on stages of grief (denial, anger, bargaining, depression, and acceptance) and a general emphasis on acceptance counseling as an indicator of bereavement resolution prove problematic for bereaved mothers ${ }^{(15)}$. Nursing care grounded in contemporary theories, such as the theory of continuing bonds, may have greater effectiveness in this distinct subtype of grief, as they suggest that relationships with the deceased are reshaped and maintained rather than abandoned ${ }^{(36)}$.

From this perspective, interventions such as reminiscence activities can collaborate to the management of feelings of emptiness and grief by providing the opportunity for mothers to feel connected to the child in her new reality and to reminisce about her life. It is also a way for them to experience support from friends, family, health professionals, and the community ${ }^{(37)}$. 
Although she presents difficulties in expressing her feelings, the mother tries to explain her pain by comparing it to other losses, such as those resulting from other adult or elderly relatives, highlighting the differentiation by the unexpected character of her child's death, that is, because it occurred in childhood and came from an apparently preventable cause. In this perspective, the mother levels up to what the common perception determines as the expected cycle of life: children should die after their parents ${ }^{(21)}$.

It is inferred that the intensity and extent of the maternal mourning response are theoretically due to the interruption of the natural order of life. Therefore, maternal impropriety in relation to being-toward-death is highlighted, when, being thrown into a bereaved world, and now aware of the fragility of existence, they do not accept this facticity. In this context, nurses have the role of avoiding possible complications in the process of maternal mourning elaboration, since nursing has a timeless character in the maintenance of care and humanization, being present in the most diverse points of the Health Care Network. Thus, the development of effective strategies for the continuous care of bereaved mothers is envisioned ${ }^{(38)}$.

When expressing her feelings about the death of her child, it is also revealed the fear that brings uneasiness and limitations to her life and that of her/ his other children. In Heideggerian analysis, the phenomenon of fear is characterized as an improper disposition, since it is determined by what is detrimentally approached in the surrounding world by the beings that come to meet it ${ }^{(21)}$.

Due to the death of her child by a domestic accident, the mother does not leave her other children unsupervised. She feels uncomfortable when he goes to school, fears to receive the news that something happened to him/her, does not allow him/her to experience routines or develop actions equal or similar to those that culminated with the death of the deceased brother. At the same time, their experience modifies the future when they fear a new pregnancy.

In her reconfigured daily life after the domestic accident that victimized her child, the mother becomes afraid of the possibility of new accidents and, above all, of other children dying. This harmful event, the domestic accident, is known and remains a threat within the conjuncture in which the family finds itself: the river is still at the margins of the house, the (poisonous) yuca can still be eaten, the iron and the fan (electric energy) are still in use. Approaching the proximity, the domestic accident threatens, as it may or may not occur again. Therefore, there is a possibility that the domestic accident will not happen, however, this does not diminish or solve the fear: on the contrary, it constitutes a threat ${ }^{(21)}$.

The phenomenon of fear has the following constitutive moments: dread, horror, and terror. In the facticity of having lost the child to a domestic accident, fear becomes dread, in view of being what threatens something known and familiar ${ }^{(21)}$. Childhood death is now part of the lived being-there-mother, for this tragedy has suddenly befallen her family when she expected it to happen only in other people's families.

In this sense, enabling the expansion of mothers' knowledge about the prevention of domestic accidents and first aid will contribute to increase their confidence in their ability to mother and protect their other children, which can collaborate to manage fear and reduce the impacts that infant death brought to their lives and their families. Therefore, educational interventions carried out by health professionals are effective in this context ${ }^{(39)}$.

\section{Study limitations}

Based on the analysis performed, it is recommended, in order to contribute to the deepening of the discussions presented here, the performance of new studies that allow a wider understanding of the facets that the research in question was limited to cover. Among these is the possibility of approaching other members of the family that were mentioned in the reports of the mothers as co-participants in the experience and pain, especially other children and spouse.

\section{Contributions to the field of Nursing, health and public policy}

The unveiling of the maternal experience based on the death of a child by accidental cause in childhood suggests that the strengthening of comprehensive care, considering the subjectivity of these mothers and establishing empathy, is an urgent issue. It is necessary to discuss death, demystify it, even if it occurs in childhood, and put it back in its position as a phenomenon intrinsic to life, avoiding the secrecy and difficulties of approach that still surround this theme and that generate significant and additional suffering to mothers and families dealing with the loss. The recommendation is that the planning of care in the assistance to maternal bereavement should be made considering three essential elements: 1) Need for an integral approach, which allows the unveiling of the essence of being, so that, in fact, the real demands of these mothers can be found, since these people have shown themselves to be inauthentic in their existential movement; 2) Development of gradual adjustment strategies to bereavement, based on maintaining the memory of the child and ongoing bonds, unlike what is often advocated in traditional approaches to bereavement; 3) Realization of educational interventions about the prevention of domestic accidents in childhood and the performance of first aid in order to manage maternal fear of the possibility of new injuries.

\section{FINAL CONSIDERATIONS}

The death of a child as a constituent and possibility of being a mother, far from representing absence, in the sense of negativity, is part of the unveiled horizon of possibilities that guarantee the reality of being. With the death of her child, this mother did not stop being a mother; she only changed her way of being by being thrown into this facticity. The fact that her child died in childhood because of a domestic accident still constitutes the phenomenal possibility of being a mother. On the other hand, it is necessary to consider that this death brings significant and permanent repercussions for the family and maternal experience; when the cause of death is apparently preventable, as in the case of domestic accidents, the bereavement becomes more complex. Because of this, in general, the absence of the child is connected to guilt; to the feeling of having failed in their role of protection and care, as well as to the fear of new accidents occurring in daily life. 
It was revealed that the death of the child in childhood compromises the integrity of being a mother, which indicates the need for systematic, humanized, qualified and continuous care for the proper conduct of the emotional and social effects related to maternal grief. In this context, health professionals, especially nurses, can allow mothers to talk about their experiences, their child, and the feelings that arise from her death. Furthermore, the support of the family and its social network can also contribute to the mother's bio-psychosocial and spiritual well-being. To this end, it is necessary to break the taboos that establish silence about death in childhood and make it difficult for the woman to adjust to the new reality.

\section{REFERENCES}

1. Al Rumhi A, Al Awisi H, Al Buwaiqi M, Al Rabaani S. Home Accidents among Children: a retrospective study at a tertiary care center in Oman. Oman Med J. 2020;35(1):e85. https://doi.org/10.1097/MD.0000000000001378

2. Murphy SL, Mathews TJ, Martin JA, Minkovitz CS, Strobino DM. Annual Summary of Vital Statistics: 2013-2014. Pediatrics. 2017;139(6):e20163239. https://doi.org/10.1542/peds.2016-3239

3. Ministério da Saúde (BR). Datasus. Informações de saúde. Estatísticas de mortalidade: óbitos por ocorrência segundo causas externas do Brasil [Internet]. Brasília: Ministério da Saúde; 2017 [cited 2019 Feb 17]. Available from: http://tabnet.datasus.gov.br/cgi/tabcgi.exe?sim/cnv/ ext10uf.def

4. Ministério da Saúde (BR). Gabinete do Ministro. Portaria n 1.130, de 5 de agosto de 2015. Institui a Política Nacional de Atenção Integral à Saúde da Criança (PNAISC) no âmbito do Sistema Único de Saúde (SUS) [Internet]. Brasília: Ministério da Saúde; 2017 [cited 2021 Sep 18]. Available from: https://bvsms.saude.gov.br/bvs/saudelegis/gm/2015/prt1130_05_08_2015.html

5. Ministério da Saúde (BR). Secretaria de Atenção à Saúde. Departamento de Atenção Básica. Saúde da criança: crescimento e desenvolvimento [Internet]. Brasília: Ministério da Saúde; 2017 [cited 2021 Set 18]. Available from: https://bvsms.saude.gov.br/bvs/ saudelegis/gm/2015/prt1130_05_08_2015.html

6. Rocha AM, Cunha NGT, Paula LN, Oliveira JIL, Cruz MVO, Praxedes TF. A atuação do enfermeiro na prevenção de acidentes na infância. Rev Interdiscip. 2020;13(1):17. https://dialnet.unirioja.es/servlet/articulo?codigo=7981224

7. Morris S, Fletcher K, Goldstein R. The grief of parents after the death of a young child. J Clin Psychol Med Settings. 2019;26(3):321-38. https:// doi.org/10.1007/s10880-018-9590-7

8. Gerrish NJ, Bailey S. Maternal grief: a qualitative investigation of mothers' responses to the death of a child from cancer. Omega J Death Dying. 2020;81(2):197-241. https://doi.org/10.1177/0030222818762190

9. Zetumer S, Young I, Shear MK, Skritskaya N, Lebowitz B, Simon N, Reynolds C, et al. The impact of losing a child on the clinical presentation of complicated grief. J Affect Disord. 2015;170:15-21. https://doi.org/10.1016/j.jad.2014.08.021

10. Price JE, Jones AM. Living through the life-altering loss of a child: a narrative review. Issues Compr Pediatr Nurs. 2015;38(3):222-40. https:// doi.org/10.3109/01460862.2015.1045102

11. Proulx M, Martinez AM, Carnevale F, Legault A. Fathers' experience after the death of their child (Aged 1-17 Years). Omega J Death Dying. 2016;73(4):308-25. https://doi.org/10.1177/0030222815590715

12. Snaman JM, Kaye EC, Torres C, Gibson D, Baker JN. Parental grief following the death of a child from cancer: the ongoing odyssey. Pediatr Blood Cancer. 2016;63(9):1594-602. https://doi.org/10.1002/pbc.26046

13. Huh HJ, Huh S, Lee SH, Chae JH. Unresolved bereavement and other mental health problems in parents of the sewol ferry accident after 18 months. Psychiatry Investig. 2017;14(3):231. https://doi.org/10.4306\%2Fpi.2017.14.3.231

14. Wall-Wieler E, Roos LL, Bolton J. Duration of maternal mental health-related outcomes after an infant's death: A retrospective matched cohort study using linkable administrative data. Depress Anxiety. 2018;35(4):305-12. https://doi.org/10.1002/da.22729

15. Goldstein RD, Lederman RI, Lichtenthal WG, Morris SE, Human M, Elliott AJ, et al. PASS Network. the grief of mothers after the sudden unexpected death of their infants. Pediatrics. 2018;141(5):e2017365. https://doi.org/10.1542/peds.2017-3651

16. Lopes BG, Borges PKO, Garden CR, Corasassi CE, Sales CM, Damasceno NFP. Maternal mourning: pain and coping with the loss of a baby. Rev Rene. 2017;18(3):307-13. https://doi.org/10.15253/2175-6783.2017000300004

17. Delalibera M, Presa J, Coelho A, Barbosa A, Franco MHP. Family dynamics during the grieving process: a systematic literature review. Ciênc Saúde Coletiva. 2015; 20(4):1119-34. https://doi.org/10.1590/1413-81232015204.09562014

18. Denhup CY. A new state of being: the lived experience of parental bereavement. Omega J Death Dying. 2017;74(3):345-60. https://doi. org/10.1177/0030222815598455

19. Liu L, Oza S, Hogan D, Perin J, Rudan I, Lawn JE, et al. Global, regional, and national causes of child mortality in 2000-13, with projections to inform post-2015 priorities: an updated systematic analysis. Lancet. 2015;385(9966):430-40. https://doi.org/10.1016/S0140-6736(14)61698-6

20. Koyanagi A, Oh H, Haro JM, Hirayama F, DeVylder J. Child death and maternal psychosis-like experiences in 44 low-and middle-income countries: the role of depression. Schizophr Res. 2017;183:41-6. https://doi.org/10.1016/j.schres.2016.11.012

21. Heidegger M. Ser e Tempo. 10. ed. Rio de Janeiro: Vozes; 2015. 
22. Paula CC, Padoin SMM, Terra MG, Souza IEO, Cabral IE. Modos de condução da entrevista em pesquisa fenomenológica: relato de experiência. Rev Bras Enferm. 2014;67(3):468-72. https://doi.org/10.5935/0034-7167.20140063

23. Casellato G. Luto pela perda de um filho: a recuperação possível diante do pior tipo de perda. In: Franco MHP. Uma jornada sobre o luto a morte e o luto sob diferentes olhares. Campinas, SP: Livro Pleno; 2002. p. 11-21.

24. Amorim TV, Souza IEO, Salimena AMO, Padoin SMM, Melo RCJ. Operationality of concepts in Heideggerian phenomenological investigation: epistemological reflection on Nursing. Rev Bras Enferm. 2019;72(1):304-8. https://doi.org/10.1590/0034-7167-2017-0941

25. Amorim TV, Souza IEO, Salimena AMO, Queiroz ABA, Elias EA. Women with cardiopathy in the context of reproductive planning: contributions of phenomenological hermeneutics. Esc Anna Nery. 2020;24(1):e20190164. https://doi. org/10.1590/2177-9465-ean-2019-0164

26. Zveiter M, Souza IEO. Solicitude constituting the care of obstetric nurses for women-giving-birth-at-the-birth-house. Esc Anna Nery. 2015; 19(1):86-92. https://doi.org/10.5935/1414-8145.20150012

27. Schmidt L. Hermenêutica. 2. ed. Petrópolis, RJ: Vozes; 2013.

28. Langendorf TF, Souza IEO, Padoin SMM, Paula CC, Queiroz ABA, Moura MAV et al. Possibilities of care for sorodiscordant couples for HIV who got pregnant. Rev Bras Enferm. 2017;70(6):1199-205. https://doi.org/10.1590/0034-7167-2016-0344

29. Rodrigues L, Lima DD, Jesus JVF, Lavorato Neto G, Turato ER, Campos CJG. Understanding bereavement experiences of mothers facing the loss of newborn infants. Rev Bras Saúde Mater Infant. 2020;20(1):65-72. https://doi.org/10.1590/1806-93042020000100005

30. Fuchs, T. Presence in absence. The ambiguous phenomenology of grief. Phenomenol Cogn Sci. 2018;17(1):43-63. https://doi.org/10.1007/ s11097-017-9506-2

31. Oliveira ALB, Menezes TMO. The meaning of religion/religiosity for the elderly. Rev Bras Enferm. 2018;71(suppl 2):770-6. https://doi. org/10.1590/0034-7167-2017-0120

32. Meisenhelder JB. Maternal grief: analysis and therapeutic recommendations. BMJ Support. Palliat. Care. 2021;11(1):101-6. https://doi. org/10.1136/bmjspcare-2020-002673.

33. Paris GF, Montigny F, Pelloso SM. Professional practice in caring for maternal grief in the face of stillbirth in two countries. Rev Bras Enferm. 2021;74. https://doi.org/10.1590/0034-7167-2020-0253

34. Razeq NMA, Al-Gamal E. Maternal bereavement: Mothers' lived experience of losing a newborn infant in Jordan. J Hosp Palliat Nurs. 2018;20(2):137-145. https://doi.org/10.1097/NJH.0000000000000417

35. Ramos CM, Pacheco ZML, Vargas IMA, Araújo PA. Existential analysis of mothers in the care of their children with Sickle Cell Disease. Rev Bras Enferm. 2020;73(Suppl 4):e20180521. https://doi.org/10.1590/0034-7167-2018-0521

36. Klass D. Continuing conversation about continuing bonds. Death Stud. 2006;30(9):843-8. https://doi.org/10.1080/07481180600886959

37. Kochen EM, Jenken F, Boelen PA, Deben LMA, Fahner JC, Hoogen A, et al. When a child dies: a systematic review of well-defined parentfocused bereavement interventions and their alignment with grief-and loss theories. BMC Palliat Care. 2020;19(1):1-22. https://doi. org/10.1186/s12904-020-0529-z

38. Santos MR, Wiegand DLMH, Sá NN, Misko MD, Szylit R. Da hospitalização ao luto: significados atribuídos por pais aos relacionamentos com profissionais em oncologia pediátrica. Rev Esc Enferm USP. 2019;53. https://doi.org/10.1590/S1980-220X2018049603521

39. Barcelos RS, Del-Ponte B, Santos IS. Interventions to reduce accidents in childhood: a systematic review. J Pediatr. 2018;94:351-67. https:// doi.org/10.1016/j.jped.2017.10.010 